\title{
Natural Physical Disturbances and Communities of Marine Soft Bottoms
}

\author{
David Thistle \\ Department of Oceanography, Florida State University, Tallahassee, Florida 32306, USA
}

\begin{abstract}
Natural physical disturbances have been shown to be important in the organization of a variety of terrestrial and marine communities. Some workers have suggested that disturbance may play a similar role in soft-bottom infauna communities. A consequence of such a view is the expectation that some species will become unusually abundant early in the recolonization of a disturbed patch, reflecting their dependence on disturbed localities for their persistence in the local community. 1 have reviewed the literature on soft-bottom communutes and have shown that some specles become unusually abundant early in the recovery of a disturbed patch. The time course of the response of these species varies from hours to months, apparently reflecting differences in life-history strategies. However, it is not clear that these species are responding to a release of resources caused by the absence of their competitors as predicted. These species may be responding to a resource provided by the disturbance without reference to competitors. Although present models provide a useful conceptual framework, a rigorous theory of how disturbance functions in soft-bottom communities has not emerged.
\end{abstract}

\section{INTRODUCTION}

Natural physical disturbance has been recognized as a structuring force in many communities, e.g. prairie plants (Platt, 1975), racky intertidal invertebrates (Dayton, 1971; Osman, 1977), rocky intertidal algae (Sousa, 1979), coral reef corals (Connell, 1978) (see Fox, 1979). In marine soft-bottom habitats, a variety of natural disturbances can create areas of opened habitat, e.g. salinity reduction (Boesch et al. 1976), storm-induced surge (Rees et al. 1977), red tide-induced fish kills (Simon and Dauer, 1972), digging by foraging rays (VanBlaricom, 1978; Reidenauer and Thistle, in press). From the above, the areal extent of a disturbed patch and the frequency with which patches are produced vary markedly depending on the disturbing agent. For species to adapt to a disturbance, it must occur frequently enough for there to be a reasonable expectation that it will occur within the lifetime of an individual. Such disturbances are termed disasters (Harper, 1977; Paine, 1979). Not all of the disturbances documented for marine soft bottoms meet this crite- rion. It is disasters that have been incorporated into models of soft-bottom community structure (Johnson, 1970, 1973; Grassle and Sanders, 1973).

In Johnson's $(1970,1973)$ model, a disturbance creates a patch where the number of species is reduced. In the time following a disturbance, species recolonize in a prescribed order without displacing those already present; the species that are most easily displaced by disturbance are last to recolonize. Johnson views the soft-bottom benthos as a mosaic of patches caused by disturbance that have different species compositions depending on their state of recovery. In Grassle and Sanders' (1973) model, disturbance also creates a spatial and temporal mosaic, but the species succession proceeds differently. In their model, species termed opportunists have evolved life-history characteristics such as rapid dispersal and high reproductive rates that allow them to locate and colonize disturbed patches rapidly so that these species occur early in succession. Other species that are better resource competitors invade later and displace the opportunists only to be themselves displaced by succeeding colonists. 
Species persist in the community because, at any given time, patches exist locally that are in the appropriate successional state for the species to colonize either by larval settlement or adult migration. Johnson (1970) contributed the idea that disturbances create a spatial and temporal mosaic in soft-bottom benthic communities. Grassle and Sanders (1973) suggested how the existence of such a mosaic could permit the persistence of species in a community where they were competitively inferior Gray (1976) incorporated the spatial mosaic concept into his argument that neighborhood stability characterized soft-bottom communities, but he did not discuss the retention of species within the community as a result of disturbance, the central issue in this review.

In a test of the disturbance model of soft-bottom community organization, the critical observation would be that in the presence of natural disturbances a species persists, and in the absence of disturbance it goes locally extinct. No experiments of this type have been reported. However, a key feature of the disturbance model is that those species kept in the community by disturbance will exploit the early portion of the recovery of the disturbed patch. It is this prediction. that has been used in experimental tests of the model (e.g. VanBlaricom, 1978; Thistle, 1980). (Granted, species could exploit the disturbed patch without becoming unusually abundant in it, but no data have been reported to support this manner by which disturbance could keep a species in the community.) Further, this criterion of disproportionate abundance provides a way of examining a variety of recolonization studies for evidence of species responses to disturbances as predicted by the model. I confine my attention to studies of natural disturbances and to studies in which the authors suggest that they have used experimental analogues of natural disturbances, i.e. settling boxes, because it is only this type of disturbance that can have played a role in organizing communities over evolutionary time. Pearson and Rosenberg (1978) review the large literature on succession involving pollution and soft-bottom communities (see also Gray, 1979)

\section{EXPERIMENTAL STUDIES ON NATURAL DISTURBANCES}

VanBlaricom (1978) studied a subtidal, invertebrate community where the near-surface species were displaced from pits made by feeding rays. He evaluated the impact of this chronic source of opened habitat by performing a series of field experiments in which he monitored the recovery of the more abundant species. In his first experiment, he sampled paired natural-pit and control areas on Days $0,7,14,28,42$, and 56 . Two amphipod species, Acuminodeutopus heteruropus and Synchelidium shoemakeri, exceeded their background abundance on Days 7 and 14 and then resumed background levels. The tanaid Leptochelia dubia exceeded its background abundance on Days 14 and 28. In a second experiment, VanBlaricom made artificial ray pits and sampled these at much shorter intervals: 1,2 , 3,4 , and 6 days after disturbance. This experiment showed that $S$. shoemakeri exceeded its background abundance from Day 1 , and $A$. heteruropus exceeded its background abundance by Day 6. The experiment also detected very rapid responses by the amphipod Megaluropus longimerus and the ostracod Parasterope sp. They were more abundant in pit samples than in background samples on only the first sampling day. These species responded as if they were exploiting the disturbed patch.

For 2 species, VanBlaricom investigated the response further. He created 2 types of artificial pits. One

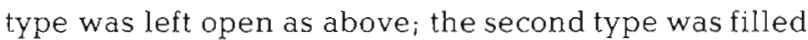
with sediment that lacked macrofauna. Both pit types were opened habitat, but the first set was also a catchment. In samples taken on Day 6, Acuminodeutopus heteruropus and Synchelidium shoemakeri showed the expected response in the pit mimic but not in the filled pit. For these species then, the absence of their competitors was not the source of the response. Because they can swim well enough to escape, VanBlaricom inferred that these species were not simply being trapped in the pit. Rather, because the pit mimic trapped drifting organic debris and these species feed on organic matter at the sediment surface, VanBlaricom suggested that it was this concentration of food that attracted the colonizers.

VanBlaricom offers this overview when a ray creates a pit, it is rapidly colonized from the plankton by a small number of species for whom resources in ambient sediments are in low supply These animals increase in numbers rapidly and exceed their background abundances, presumably exploiting the enhanced resource levels of the pits. In time, their numbers decline. VanBlaricom found no evidence of competitively caused decreases in abundance; he attributed the decline to changing food quality These animals then reenter the plankton and search out another pit.

Sherman and Coull (1980) defaunated a 9-m² area of intertidal mud bar in South Carolina, USA. They followed the recolonization of total nematodes, total harpacticoid copepods, and total foraminiferans, as well as nematodes and harpacticoids at the species level (see also Scheibel, 1974; and Scheibel and Rumohr, 1979). Recolonization was rapid; densities of all taxa in the first post-disturbance samples ( $12 \mathrm{~h}$ ), could not be distinguished from controls. No nematode or harpac- 
ticoid species differed in its abundance from control levels in the post-disturbance samples, that is, no species showed the expected increase in response to opened habitat.

In the shallow subtidal of the Gulf of Mexico, the acorn worm Ptychodera bahamensis occurs frequently and makes fecal mounds (median diameter $=5 \mathrm{~cm}$ ) on the sediment surface. The mounds are patches in the habitat where harpacticoid densities are seven times lower than background densities. Thistle (1980) followed the recolonization by harpacticoids of these opened patches, sampling at $0,4,23$, and $28 \mathrm{~h}$ after initiation of recolonization. Harpacticoid densities no longer differed from background densities by $23 \mathrm{~h}$. Thistle reported that of the 16 species he tested for disproportionate abundance in mounds only Robertgurneya rostrata at $0 \mathrm{~h}$ and Pseudobradya c. f. exilis at $4 \mathrm{~h}$ were significant. These species responded as if they were exploiting a disturbed patch.

In an adjacent site, Reidenauer and Thistle (in press) studied the recolonization by harpacticoid copepods of stingray (Dasyatis sabina) feeding pits. Stingray pits averaged $30 \mathrm{~cm}$ in diameter and typically covered 4.5 $\%$ of the bottom in this habitat. Ray feeding disperses the upper sediment layers where harpacticoids live; newly made pits contain 5 times fewer harpacticoids than the surrounding sediment. Reidenauer and Thistle studied the recovery of the harpacticoid fauna by following 3 newly made pits over 5 days, sampling on Days 1, 2, 3, and 5. Again, the recovery was rapid. The significant difference between pit and background samples in total harpactioid abundance disappeared by Day 2. However, no species was significantly disproportionately abundant in pit samples at any time. In particular. Robertgurneya rostrata and Pseudobradya c. f. exilis, the species that responded to the acorn worm fecal mounds, occurred in this habitat but were not disproportionately abundant in the pit during recolonization.

Sherman et al. (submitted) studied the nematodes from the experiment described above. In freshly made pits, nematode densities were 4 times lower than background samples. Nematode abundances took until Day 5 to recover. However, no species became significantly disproportionately abundant during recolonization.

\section{OTHER EVIDENCE}

Some work has been done on the recovery of natural disturbances of large magnitude. Because of the infrequency and localized nature of such disturbances, it seems unlikely that species have evolved adaptations specifically to exploit them. They are not the chronic, small-scale, ubiquitous disturbances of the models.
However, their study may help to identify species that respond to disasters. Unfortunately, much of this work has not been reported at the species level. An exception is the study of Simon and Dauer $(1972,1977)$.

Simon and Dauer (1972) reported defaunation of an intertidal sand beach as a result of a red tide-induced fish kill and subsequent anoxia in the sediment; $97 \%$ of the infaunal invertebrates died. Simon and Dauer (1977) followed recolonization by polychaetes at the species level during 2 years of monthly samples. Five species became unusually abundant early in recolonization, Polydora ligni and $P$. socialis at Time 1 , and Nereis succinea, Eteone heteropoda, and Paraprionospio pinnata at Time 2 (see also Dauer and Simon, $1976 a, b)$. Although there were no control data, these species reached abundances at these times that they never approached in later samples. Therefore, it seems reasonable to suggest that these species may have shown the predicted increase in abundance of species exploiting disturbance-opened habitat (see also Watling, 1975; Boesch et al., 1976).

A second type of data comes from the studies of the recolonization of containers of defaunated sediment. Grassle and Grassle (1974) studied the recolonization of boxes filled with sediment defaunated by freezing and thawing and emplaced with the surface flush with the surrounding sediment. In shallow-subtidal sites in Massachusetts (USA), they found that the polychaete Capitella capitata increased to background densities within $12 \mathrm{~d}$. The box populations crashed after 2 months. By repeating the experiment with boxes staggered in time, they were able to show that the decline was neither a seasonal nor a predator-caused event but appeared to result from the intraspecific depletion of resources.

McCall (1977) conducted a similar experiment in Long Island Sound except that his sediment boxes were in racks rather than being emplaced in the sea floor (see also Richter and Sarnthein, 1977). He took his first box and background samples $10 \mathrm{~d}$ after the boxes were emplaced. At this time, the polychaetes Streblospio benedicti and Capitella capitata had increased from 0 to 418315 and 36120 individuals $/ \mathrm{m}^{-2}$ respectively. Each species exceeded its background abundance by about 100 fold. The amphipod Ampelisca abdita increased from 0 to $5130 \mathrm{~m}^{-2}$, nearly twice its background abundance. These species appeared to be exploiting a mimic of a natural disturbance. In McCall's samples, these early colonists showed the die off that Grassle and Grassle (1974) observed. McCall used Grassle and Grassle's (1974) offset-box technique to show that the colonizing species could increase and decrease in abundance simultaneously, suggesting that the die off was not seasonal or predation-induced but internal to the box. 
In a field survey in conjunction with his experiments, McCall (1977) found that samples in which colonizing species made up over $70 \%$ of the individuals occurred only above $25 \mathrm{~m}$ depth in Long Island Sound. This depth was a reasonable estimate of the lowest depth to which winter storms eroded the bottom. McCall inferred that the field distribution of colonizing species reflected their response to the disturbed patches created by winter storms, suggesting that disturbances were important for the persistence of these species

Two settling-box experiments have been done in the deep sea. Grassle $(1977,1978)$ worked at $1760 \mathrm{~m}$ depth near Bermuda. After 26 months on the bottom, Grassle's box had an order of magnitude lower faunal density than the background. In contrast, Desbruyères et al. (1980) found 5 times the background density after 6 months in a similar experiment at $2160 \mathrm{~m}$ depth in the Bay of Biscay. In Grassle's experiment, 7 of the 10 most abundant species were not found in background samples. These species could be interpreted as showing increased abundance in the disturbance mimic. Desbruyères et al. also found that the fauna in their box differed radically from that in nearby bottom samples. Prionospio sp. made up $82 \%$ of the fauna; Ophryotrocha puerilis was also abundant. Neither was present in background samples. The authors suggested that these were opportunist species responding as they would to a natural disturbance.

\section{DISCUSSION}

The work to date on natural physical disturbances appears to provide support for the Grassle and Sanders (1973) model in that disturbances do create patches and species do appear to exploit them. The time courses of species responses to a disturbed patch are varied. Pseudobradya c.f. exilis responded at $4 \mathrm{~h}$, Megaluropus longimerus and Parasteropesp. at 1 day Acuminodeutopus heteruropus and Synchelidium shoemakeri exceeded background abundances from Days 6-14 and 1-14 respectively. For Simon and Dauer's (1977) polychaetes, it is unclear how rapidly they colonized because the first samples were on the order of weeks after recolonization began, but the species that colonized early tended to remain above background levels for $1-2$ months.

The continuum of response times suggests that there is a continuum in the life-history strategies of species that exploit disturbances. At one extreme, species like Megaluropus longimerus and Pseudobradya c. f. exilis spend only a small portion of their life cycle in a given patch; the patch is a place where individuals can get a 'good meal'. Each individual must then exploit many patches in its lifetime. Further, $P$. c f exilis is not rare in the environment, so that exploiting a disturbance may be only part of a successful life-history strategy. At the opposite extreme are species that are adapted to grow up and reproduce in a single patch, e.g. Capitella capitata.

Several authors have described life-history traits that appear to characterize early-colonizing species based on the animals they studied (McCall, 1977; VanBlaricom, 1978; Dauer, 1980; Santos and Simon, 1980), but there is little agreement among them. Early colonizing species seem to feed at the sediment surface, and these species have a life stage that is dispersed via the water column although there may be exceptions even to this generalization, e. g. the manner of Eteone heteropoda recolonization is unknown (Simon, pers. comm.). Among the macrofauna, sedentary adults ('discretely motile'; Jumars and Fauchald, 1977) are common.

The data in support of the model are not unequivocal. Only a small number of species have been shown to become abundant early in the recovery of a naturally disturbed patch. These species may respond for reasons other than those specified in the model. For Acuminodeutopus heteruropus and Synchelidium shoemakeri, VanBlaricom (1978) has shown that it is not the reduction in competition caused by displacement of the background fauna from the pit that explains the increase in the abundance of these species. Rather, he suggests that it is the result of the concentration of resources caused by the catchment action of the pit. Thistle's (1980) data on Pseudobradya c. f. exilis and Robertgurneya rostrata may fit this pattern as well. These species became disproportionately abundant during the recolonization of acorn worm fecal mounds but did not differ from background abundance in recovering ray pits. If these species were responding to reduced competition, they should respond to the ray pit; it is larger and persists longer as a feature than the fecal mounds. The fecal mound has a microbial flora of different character than that of the surrounding sediment (D. C. White, pers. comm.). Harpacticoids feed on microbes; the response of these species to the mound may be a response to the provision of a resource by the disturbance. Also, Whitlach (1980) has reinterpreted Johnsons's (1970) data in terms of a food gradient rather than a disturbance gradient.

These results suggest that these species could be responding to a favorable resource situation created by the disturbance rather than to a favorable resource situation resulting from a temporary reduction in their competitors as in the model Therefore, this alternative hypothesis should be entertained before accepting data as supporting the model. In Simon and Dauer's study $(1972,1977)$, the alternative explanation is plausible in that the red tide killed the ambient fauna 
in place. Grassle and Grassle (1974) prepared the sediment for their boxes by freezing and thawing; they mentioned that the sediment contained decaying animals. McCall's (1977) boxes were filled with an organic-rich harbor mud. Some of his boxes received an overlay of $2-3 \mathrm{~cm}$ of resuspended material. This material is likely to be finer than the background sediment and may be enriched in preferred particle sizes for deposit feeders (Taghon et al., 1978). Streblospio benedicti and Capitella capitata were the 2 polychaete species to colonize these boxes rapidly and massively; Whitlach (1980) has shown that these species prefer to feed on fine particles. Grassle (1977) collected deep-sea sediment with an anchor dredge to fill his boxes. The material was frozen and and thawed. From the way an anchor dredge samples (Sanders et al., 1965), it seems likely that the box contained decayed animals. Desbruyères et al. (1980) used sediment collected with a box core from their abyssal site and a site at $100 \mathrm{~m}$. They killed the fauna in place by freezing and thawing so that their sediments were enriched. In all these studies, the recolonization could have been in response to the provision of a resource independent of the relaxation of competition.

Grassle and Grassle (1974) point to Capitella capitata and Streblospio benedicti as dramatic exploiters of disturbed areas. Whitlach (1980), in his study of the niche relationships of a shallow-water depositfeeder assemblage in Massachusetts, found that $S$. benedicti and $C$. capitata were resource specialists and habitat generalists. They appear to be good competitors in contrast to the predictions of the model. It seems likely that their response to disturbance is to the provision of a resource.

These results seem to require an alternative phrasing of the model. The data are neutral in terms of the view that early colonizing species are exploiting the resources released by the absence of their competitors. However, the data do suggest that disturbances can provide resources, e. g. the concentration of drift organic matter (VanBlaricom, 1978), and that some species have adapted to include the exploitation of these resources in their life histories. If these species are resource specialists as suggested in Whitlach's (1980) results, then their disappearance from aging disturbed patches may result from the exhaustion of a resource rather than their displacement by later colonists. Disturbances may still be necessary for the continued persistence of the species in the community, but the mechanism may be different than previously postulated.

This review has concentrated on the response of species to a disturbed patch, but disturbance can play other roles in soft-bottom communities. In some areas. particular species (or functional groups of species) occur in dense stands that alternate in space or in time with dense stands of other species (Woodin, 1976). Eagle (1975) suggested that this patch structure could arise and be perpetuated if disturbance opened patches that were densely settled by that species with abundant larvae in the water when the patch was opened and if the alternating species had different reproductive periods. Woodin and Yorke (1975) provide a mathematical model for this process

To summarize, small-scale disturbances create patches that are recolonized. When patches are not disturbed simultaneously, a mosaic of states of recolonization occurs. Species that become unusually abundant early in recolonization seem to be responding to resources, but it is not clear whether the mere relaxation of competition for background resources is important. The time course of individual species' responses varies from hours to months, apparently reflecting different strategies of exploitation. Some generalizations appear to be emerging about the adaptations common to these species. Although the Grassle and Sanders (1973) model provides a useful conceptual framework, a rigorous theory of how disturbance functions in softbottom communities has not yet emerged.

Acknowledgements. I would like to thank the following individuals for their comments on the manuscript: S. S. Bell, P. K. Dayton, K. M. Sherman, J. L. Simon, and A. B. Thistle. This research was supported, in part, by the Office of Naval Research contract N00014-75-C-0201.

\section{LITERATURE CITED}

Boesch, D. F., Diaz, R. J., Virnstein, R. W (1976). Elfects of Tropical Storm Agnes on soft-boltom macrobenthic communities of the James and York estuaries and the Lower Chesapeake Bay. Chesapeake Sci. 17: 246-259

Connell, J. H. (1978). Diversity in tropical rain forests and coral reefs. Science, N. Y 199: 1302-1310

Dauer, D. M. (1980). Population dynamics of the polychaetous annelids of an intertidal habitat in upper Old Tampa Bay Florida. Int. Revue ges. Hydrobiol. 65: 461-487

Dauer, D. M., Simon, J. L. (1976a). Habitat expansion among polychaetous annelids repopulating a defaunated marine habitat. Mar. Biol. 37: 169-177

Dauer, D. M., Simon, J. L., (1976b). Repopulation of the polychaete fauna of an intertidal habitat following natural defaunation: species equilibrium. Oecologia 22: 99-117

Dayton, P. K. (1971). Competition, disturbance, and community organization: the provision and subsequent utilization of space in a rocky intertidal community. Ecol. Monogr 41: 351-389

Desbruyères, D., Bervas, J. Y., Khripounoff, A. (1980). Un cas de colonisation rapide d'un sédiment profond. Oceanol Acta 3: 285-291

Eagle, R. A. (1975). Natural fluctuations in a soft bottom benthic community. J. mar. biol. Ass. U. K. 55: 865-878

Fox, J. F. (1979). Intermediate-disturbance hypothesis. Science, N. Y 204: 1344-1345

Grassle, J. F. (1977). Slow recolonization of deep-sea sediment. Nature, Lond. 265: 618-619 
Grassle, J. F. (1978). Diversity and population dynamics of benthic organisms. Oceanus 21 (11): $42-49$

Gracsle, J. F., Grassle, J. P. (1974) Opportunistic life hictories and genetic systems in marine benthic polychates. J. mar. Res. 32: $25.3-284$

(ifassle, J. F., Sanders, H. L. (1973). Life histories and the role of disturbance. Deep Sea Res. 20: 64.3-659

(iray, J. S. (1976). Are marine base-line surveys worth while? New Scient. 70: 219-221

Gray, J. S. (1979). Pollution-induced changes in populations. Phil. Trans. R. Soc Lond. B 286: 545-561

Harper, J. L. (1977). Population biology of plants, Academic Press, New York

Johnson, R. G. (1970). Variations in diversity within benthic marine communties. Am. Nat. 104: 285-300

Johnson. R. G. (1973). Conceptual modeis of benthic communilies. In: Schopf, T. J. M. (ed.) Models in paleobrology. Freeman Cooper and Co., San Francisco, pp. 148-159

Jumars, P. A., Fauchald, K. (1977). Between-community contrasts in successful polychaete feeding strategies. In: Coull, B. C. (ed.) Ecology of marine benthos. Unuversity of South Carolina Press, Columbia, pp. 1-20

Mccall, P. L. (1977). Community patterns and adaptive strategies of the infaunal benthos of Long Island Sound. J. mar Res. 35: 221-266

Osman, R. W. (1977). The establishment and development of a marine epifaunal community. Ecol. Monogr 47: 37-63

Paine, R. I (1979). Disaster, catastrophe, and local persistence of the sea palm Postelsia palmaeformis. Science, N. Y 205: 685-687

Pearson, T. H., Rosenberg, R. (1978). Macrobenthic succession in relation to organic enrichment and pollution of the marme environment. Oceanogr mar Biol. A. Rev. 16: 229-311

Platt, W. J. (1975). The colonization and formation of equilibrium plant species associations on badger disturbances in a tall-grass prairie Ecol. Monogr 45: 285-305

Rees, E. I. S., Nicholaidou, A., Laskaridou, P. (1977). The effects of storms on the dynamics of shallow water benthic associations. In: Keegan, B. F., Ceidigh, P. O., Boaden, P J. S. (eds.) Biology of benthic organisms. Pergamon Press, New York, pp. 465-477

Reidenauer, J. A., Thistle, D. (In press). The response of a softbottom harpacticoid copepod community to disturbance by stingrays. Mar. Biol.

Richter, W. Sarnthein, M. (1977) Molluscan colonization of different sediments on submerged platforms in the western Baltic Sea. In: Keegan, B. F., Ceidigh, P. O., Boaden, P. J. S. (eds.) Biology of benthic organisms. Pergamon Press, New York, pp. 531-539

Sanders, H. L., Hessler, R. R., Hampson, G. R. (1965). An introduction to the study of deep-sea benthic faunal assemblages along the Cin: Head-Bermuda transect. Deep Sea Res. 12: 845-867

Santos, S. L., Simon, J. L. (1980). Response of soft-bottom benthos 10 annual catastrophic disturbance in a South Florida estuary. Mar Ecol. Prog. Ser 3: 347-355

Scheibel, W (1974). Submarine experiments on benthic colonization of sediments in the Western Baltic Sca. II. Meiofauna. Mar. Biol. 28: 165-168

Scheibel, W., Rumohr, H. (1979). Meiofauna development on artificral suft bottoms in Kiel Bay. Helgolander wiss Meeresunters. 32: 305--312

Sherman, K. M., Coull, B. C. (1980). The response of meiofauna to sediment disturbance J. exp. mar. Brol. Ecol 46: $59-71$

Sherman, K. M., Reidenauer, J. A., Thistle, D., Meeter, D. A (Submitted). The response of a marine nematode community to a small-scale natural disturbance. Estuar. coast. mar. Sci.

Simon, J. L., Dauer, D. M. (1972). A quantitative evaluation of red-lide induced mass mortalities of benthic invertebrates. Environm. Lett. 3: 229-234

Simon, J. L., Dauer, D. M. (1977). Reestablishment of a benthic community following natural defaunation. In: Coull, B. C. (ed.) Ecology of marine benthos. University of South Carolina Press, Columbia, pp. 139-154

Sousa, W. P. (1979). Disturbance in marine intertidal boulder fields: the nonequilibrium of species diversity. Ecology 60: 1225-1239

Taghon, G. L., Self, R. F. L., Jumars, P. A. (1978). Predicting particle selection by deposit feeders: A model and its implications. Limnol. Oceanogr. 23: 752-759

Thistle, D. (1980). The response of a harpacticoid copepod community to a small-scale natural disturbance. $J$. mar. Res. 38: 381-395

VanBlaricom, G. R. (1978). Disturbance, predation, and resource allocation in a high energy sublittoral sandbottom ecosystem: Experimental analyses of critical structuring processes for the infaunal community. Dissertation, University of California, San Diego

Watling, L. (1975). Analysis of structural variations in a shallow estuarine deposit-feeding community. J. exp. mar Biol. Ecol. 191: 275-313

Whitlach, R. B. (1980). Patterns of resource utilization and coexistence in marine intertidal deposit-feeding communities. J. mar Res. 38: 743-765

Woodin, S. A. (1976). Adult-larval interactions in dense infaunal assemblages: patterns of abundance. J. mar. Res. $34: 25-41$

Woodin, S. A., Yorke, J. S. (1975). Disturbance, fluctuating rates of resource recruitment, and increased diversity. In: Levin, S. A. (ed.) Ecosystem analysis and prediction. Soc. Indust. Appl. Math., Philadelphia, pp. 38-41 